\title{
The New Phase and Face of International Journal of Epilepsy
}

\author{
Man Mohan Mehndiratta ${ }^{1}$ \\ 1Janakpuri Super Speciality Hospital, Janakpuri, New Delhi, India \\ Int J Epilepsy 2018;5:1-1
}

Beginning 2018, International Journal of Epilepsy, affiliated to the Indian Epilepsy Society (IES), comes with a new face for its readers. The journal will now be published by Thieme and will focus on publishing top quality original research, reviews, investigations, consensus document/position statements, multiple-choice questions, and case reports, besides regularly publishing conference proceedings, editorials, brief communications, and letters. The journal is fortunate to have internationally acclaimed epilepsy experts as reviewers.

The Indian Epilepsy Society decided to choose Thieme Delhi as the publisher of the journal because of their expertise in publishing high-quality journals in Neurosurgery (https://www.thieme.com/journals-main\#neurosurgery) and Neurology (https://www.thieme.com/journals-main\#neurology). Few notable names in these categories are Journal of Neurological Surgery, Journal of Neuroanaesthesiology and Critical Care, Seminars in Neurology, and Neuropediatrics. The journal looks forward to reaching new heights of global recognition while featuring in this list.

The journal will continue as an open access title with all its articles strictly based on double blind peer-review process. The authors are requested and advised to submit their manuscripts at www.manuscriptmanager.net/ijep, whereas the full-journal information is available to readers at www. thieme.com/ijep .

The journal, started in 2014, is now in its 5th volume and is already indexed with SCOPUS. The journal will continue to be biannual in frequency coming once every 6 months with the possibility to publish special issues. The journal since its inception has addressed various topics in epilepsy ranging from in vivo experiments addressing drug efficacy, ${ }^{1}$ in vitro experimentation addressing DNA damage and mutations related to epilepsy, ${ }^{2}$ to core clinical investigations ranging from seizures comparison in ischemic versus venous stroke ${ }^{3}$ to epidemiological investigations addressing comorbid psychiatric problems in persons with epilepsy. ${ }^{4}$ The journal shall continue to serve in updating its knowledge as a learning source for neurology residents, epilepsy experts, and practicing clinicians by regularly publishing narrative reviews related to the topics such as monotherapy in focal seizure. ${ }^{5}$

In its new journey with Thieme, the journal envisions to not only continue to serve as a medium for dissemination of knowledge and information to its readers but to eventually become the face of investigations in epilepsy coming from different parts of the world. In this quest, the journal and the society, sincerely looks forward to an active participation of its authors, reviewers, and readers to continue contributing and improving the journal ahead.

\section{References}

1 Samad A, Fatemeh H, Mojtaba K. Involvement of N-methyl$\mathrm{D}$-aspartate receptors and nitric oxide in the anticonvulsant effects of dantrolene against pentylenetetrazole-induced seizures in mice. Intl J Epilepsy 2017;04(2):112-118

2 Sekar N, Ramgir S, Prabhu YD, Renu K, Abhilas VG. Evaluation of DNA damage and mutation screening of exon 26 of SCN1A gene in patients with epilepsy. Intl J Epilepsy 2017;04(2):125-131

3 Singh RK, Bhoi SK, Kalita J, Mishra UK, Gupta D. A comparative study of seizures in arterial and venous stroke. Int J Epilepsy 2017;4(1):6-11

4 Rehman S, Kalita KK, Baruah A. A hospital based cross sectional study on comorbid psychiatric problems in persons with epilepsy from north eastern part of India. Int J Epilepsy 2017;4(1):31-35

5 Sonkusare KR, Barkate HV. Lacosamide as monotherapy in focal seizure: literature review. Int J Epilepsy 2017;4(1):55-58
Address for correspondence Man Mohan Mehndiratta, MD, DM, FRCP, Janakpuri Super Speciality Hospital, Janakpuri, New Delhi, India (e-mail: editorijep@gmail.com).
DOI https://doi.org/ 10.1055/s-0038-1668467. ISSN 2213-6320.
Copyright @2018 Indian Epilepsy Society
License terms

() (1) $\ominus \circledast$ 